\title{
Equivalence and Appropriateness: Divergence Characteristics of Categories under Translation
}

\author{
Juri Kobenko \\ Tomsk Polytechnic University \\ Email: serpentis@ list.ru
}

Alexander Ptashkin

Tomsk Polytechnic University

Email: pt.alexandr@gmail.com

Doi:10.5901/mjss.2014.v5n27p1601

\begin{abstract}
The authors deal with the notions of equivalence and appropriateness, and describe the divergence characteristics of categories under translation. Equivalence is considered as the quantitative correspondence of source text (ST) to target text (TT), while appropriateness is mentioned as the qualitative correspondence. Equivalent translation is seen in the sense of quantitative correspondence of source text and target text and their means of expression. The authors conclude that the quantitative comparison of ST and TT proves the fact of their prior nonequivalence, and sum up that it is connected with the socalled form of language and its means density. The article deals with the statement that translation might be formed among language groups that lexicalize the contents in a different way. The terms "translation" and "search for an equivalent" are differenciated. Naturalism or translation symmetry is defined as the cases of excessive attention of translators to formal part of their work; it is widely spread in the practice of translation. The terms "meaning" and "content" are mentioned in the following focus: meaning objectifies extralinguistic reality of the unit or text, content specifies intralinguistic one.
\end{abstract}

Keywords: equivalence, appropriateness, category, translation, source text, target text, correspondence

\section{Introduction}

Equivalence and Appropriateness are the linguistic expression of dialectical categories of quantity and quality (Ptashkin, 2013a; Ptashkin, 2013b). Equivalence is a quantitative correspondence of source text (ST) to target text (TT), and their means of expression (Cf. definition of the term "equivalent" in Russian encyclopedia: "equivalent (L. Latin aequivalens equipollent, equal) is the item or quantity that are tantamount, equal or corresponding to other subjects of quantities in any relation, and could serve them as the form or substitution (Prokhorov, 2001). Appropriateness is the qualitative correspondence. The key paradox of this correlation is that the translator, who is searching for quantitative correspondence (ideal form 1:1), tends to adequate translation. Cf. translation of Russian phrase «фрилькина грамота» into the German language using the lexical unit "der Wisch" in the meaning < [laienhaft erstelltes] Papierdokument ohne juristischen Werts.

What is more difficult to reach equivalent or appropriate translation? Our answer is evident - equivalent translation, i.e. quantitative correspondence of ST and TT and their means of expression. Appropriateness implies relatively free reconstruction of contents in accord with the norms of target language (TL). Equivalence reproduces the same quantity of text units. For instance, humour device that is connected with inequal translation with many words of short phrases or vise versa is widely spread in cinema. Cf. the scene in Russian film "Brilliant Arm" directed by L. Gajdaj (1968), when the angry speech of a smuggler is interpreted in Russian by the phrase "Извините, погорячился!" (Sorry, I got excited!).

\section{Research Methodology}

The wish of the translator or editor to measure both texts is the basis of equivalence view. It is quite justified because ST and TT do not coincide in number of words, lines, and pages. There is common knowledge about functional divergence and fundamental nonequivalence of the languages i.e. absence of quantitative equability between handled registers in source language (SL) and TL. It is clearly seen in the following example. Compare functional and semantic characteristics 
of personal pronouns in the second person, singular, in the English, German, and Russian languages.

Table 1. Functional and semantic characteristics of personal pronouns in the second person, singular, in the English, German, and Russian languages.

\begin{tabular}{|c|c|c|c|c|c|}
\hline $\begin{array}{c}\text { Personal } \\
\text { pronoun }\end{array}$ & $\begin{array}{c}\text { Context Meaning of impersonal } \\
\text { pronoun }\end{array}$ & Omission & $\begin{array}{c}\text { Honorific } \\
\text { meaning }\end{array}$ & $\begin{array}{c}\text { Capital letter writing } \\
\text { possibility }\end{array}$ & $\begin{array}{c}\text { Homonymy, 2 } \\
\text { plural person, }\end{array}$ \\
\hline ты & + & + & - & + & - \\
\hline $\mathrm{du}$ & + & - & - & + & - \\
\hline you & + & - & + & - & + \\
\hline
\end{tabular}

As we can see, even personal pronouns, tending to be full equivalents in daughter languages of Indo-European one, vary in meaning and speech functions i.e. they can not be considered as absolute elements. Moreover, the degree of equivalent distribution of personal pronoun, $2^{\text {nd }}$ person, plural in Russian and German is higher than in languages of the same group - German and English. Even linguistic affinity (the German language is the ancestor of the English language) can not be the reason for equivalence presence. For translator it is better to refuse of the illusion of full equivalence. It is better to bear in mind that there is nonequivalence in kindred and homologous languages; such position helps to preserve vigilance because it is advantageous for translation strategy.

Absolute equivalence does not exist. The key point is that the quantitative comparison of ST and TT proves the fact of their prior nonequivalence. There is an opinion that it is connected with the so-called form of language and its means density. For example, the German language is considered quite bulky because of its unrestricted word formation capability. This characteristic of the German language has been used from the times of M. Twain as an argument of criticism, in particular, when the question is about short borrowing that is opposed to German complex equivalent. The units "umweltverträglichkeitsprüfungspflichtig" and "Haifischschwanzflossenfleischsuppe" can not be considered laconic, but translation of these words in any other language might be longer in case of description construction usage. The form of language is not the reason of nonequivalence, but it is the method of content lexical ization. In this sense, polysynthetic languages have the benefits. They are out of linearity, and they explicate the meanings through more complex forms of sign-sentences.

Translation can be carried out among language groups that lexicalize the contents in a different way. For instance, taking into account the languages "German-English," the publisher will always save the paper, but in reverse correlation, he will spend more materials. As it is mentioned above, the type of language plays an important role: fusional and agglutinating languages use more materials than isolating ones, and analytical languages allow saving in the process of translation into synthetic ones. Examples of quantitative mismatches are numerous, some of them are presented here languages "Russian vs German" (words: words):

Table 2. Some examples of quantitative mismatches in Russian and German.

\begin{tabular}{|l|l|l|}
\hline Rus.: оказалось(, что...) & $1: 4$ & Ger.: es hat sich herausgestellt(, dass...) \\
\hline Rus.: до свадьбы заживёт & $3: 11$ & $\begin{array}{l}\text { Ger.: bist du das dritte Mal geschieden bist, } \\
\text { ist das wieder verheilt }\end{array}$ \\
\hline Rus.: на ловца и зверь бежит & $5: 3$ & Ger.: Kunst bringt Gunst \\
\hline $\begin{array}{l}\text { Rus.: получить повышение по карьерной лестнице через } \\
\text { интимную связь с руководителем }\end{array}$ & $10: 1$ & Ger.: hochschlafen \\
\hline
\end{tabular}

Translation of phrases and expressions that have no equivalents in social group culture (SGC) stands apart, for example: der Persilschein (denazification card; удостоверение денацификации), заначка (heimliches und verstecktes Ersparnis; a stash).

Certainly, lexical gap plays an important role in a process of searching for equivalents, cf. units борщ $\rightarrow$ die Kohlsuppe (der Borschtsch; red-beet soup), масленица $\rightarrow$ die russische Fastnacht (Pancake Week). That is why quantitative correspondence is required, it is actual in lexicography, where lemma registers are opposed to each other $1: 1$. 


\section{Findings and Discussion}

Translation and search for an equivalent are not the same processes. For example, Russian word «пустырник» (motherwort) can be translated in German as "Ödwurz, Heidenwurz." Unlike them, the word "Herzgespann" is an equivalent that exists in culture of nation and has tradition in history. Thus, searching for the equivalent, the translator tries to find nominalizing transformation that should be fixed in consciousness of native speakers, and be constant sign that is common, plain and knowable by the representatives of language culture.

It is apposite to correlate these criteria of comparison of ST and TT with lexical unit elements: form and content for understanding the nature of equivalence and appropriateness. Equivalence is the formal side of the translation i.e. ambition of the translator in equivalent search is connected with the selection of dictionary or corpus correspondence. The content objectifies the adequate side of translation, and is an explication of semantic direction of language unit.

The cases of excessive attention of translators to formal part of their work (the so-called "translation symmetry"; it is also known as naturalism) are widely spread in the practice. Starting point of such strategy is the false conception that any language unit of SL has the equivalence in TL of the type 1:1. This equivalence may be and should be realized in TT. Symmetry is preparedness to translate everything that can be met in ST. Such principle is titled by acronym GIGO "garbage in, garbage out" in American information science. It is used concerning the valuation of primitive computers functioning in the sense of data processing: one byte of input information is one byte of source information. Undoubtedly, an experienced translator could find an equivalent in any context, but an idea about principle-based translation of all means of $\mathrm{SL}$ is disputable.

The reason was mentioned before - nonequivalence of languages, and consequently, lexical means according to the contents and functions in speech. For example, the sememe of German verb "sich benehmen" includes the seme "good", cf.: Kinder, benehmt euch, wenn ihr zu Gast seid! Symmetrical method of many translators leads to the situation when the lexixal unit "gut" appears in TT in the process of translation from Russian into German. In German this language unit is redundant.

In next example we see the Russian version of documentary film about the building of Versailles (National Geographic), the phrase "This (= the building of Versailles in a swamp) was the choice of the king" was interpreted as "это был выбор короля." This film deals with the history of King Louis, who took the lords to Versailles bog, and decided to build the residence of French kings, in this unattractive place, "magnificence of this part will be the object of talk worldwide". Of course, lexical unit "выбор" in Russian version might be considered adequate to English "choice," i.e. it coincides with the contents and function, when the lexical unit "место" could be the object of the utterance. In this context the story does not consider the choice which means "decision considering two variants and choosing one of them" as in the Russian language, but "taking odd and freethinking idea." Appropriate variants of translation are seen in Russian as "решение / решить," "прихоть", "воля," these language untis characterize the actions of the king exactly, cf.:

1) Прихотью короля было построить Версаль на болотах.

2) И решил король построить Версаль на болотах.

3) По воле короля Версаль построили на болотах.

The same situation can be observed in the traslation of nonequivalent language units. It would be better to "solve" such nonequivalent unit of another culture, or make it "invisible" with paying no reader's attention to this obscure "idea" of foreign culture. The translator, forgetting the fact about nonequivalent language units in ST as usual means, but not the elements for special stylistic colouring, creates a "copy" of that nonequivalent language unit of ST in TT by fixing its foreign form. As a result, this process leads to incorrect perception of text and contents misrepresentation. For instance, the translation of Russian word "маршрутка" into German by using transliteration or transcription - "Marschrutka" cannot explain its content of specific reality of post Soviet society. In conversation between A and B in the Russian language as SL A constantly uses the lexical unit "маршрутка" to inform B about details of movement. B also considers it as the means of movement, and not as the type of transport that is opposed to all other kinds of means of movement in the world (and from what source could B know about kinds of transport that exist out of his reality?). Taking into account Russian form, translator persuades the reader that $A$ informs $B$ about unique post Soviet type of transport. Dialogue between $A$ and $B$ does not aim at informing $B$ about the details of movement, but it is directed at the reader who is the object of receiving information that is connected with the peculiarities of fixed-run taxi in a popular form, by means of a dialogue, and not with the help of encyclopaedic article. Evidently, translation symmetry does not justify itself even in near context comparison.

The key point in natural method is the borrowing in the process of translation. It is a real disappointment when natural word creation of translators becomes the norm. This tendency intensifies because of wide usage of American words in European languages. For example, it is common practice in German pharmaceutical industry to use in product 
packing the form of translation of the unit "care" in phrase "intensive care" by expression "intensive Pflege" instead of "ausgeprägter Effekt, wirkungsintensiv." Even unexperienced translator realizes that there is semantic, stylistic, and pragmatic heterogeneity of units under comparison $-\langle$ care $\rangle \neq\langle$ Effekt, Wirkung $>$ : firss of all, caring does not mean effect of recovery; secondly, manufacturer uses American phrase "intensive care" to goose sales without healing guarantee. German set phrase "ausgeprägter Effekt" underlines pharmacologic properties of the medicine, and helps to choose a remedy of a definite group.

Thus, optimal strategy of the translator is coordination of formal and content part of translation. It should be remembered that hypertrophy of the form leads to dystrophy of content and vice versa, i.e. why we should follow the balance between these two features in oder to have successful translation form.

Appropriateness of translation is not only an expression of content correspondence of ST and TT. As opposed to equivalence that exists in some forms, adequacy is the universal indicator of qualitative correspondence of ST and TT regardless of type (consecutive, subsidiary translations, etc.) and genre (oral, written translations).

Qulitative correspondence means coincidence of semantic (content) and functional (meaning) characteristics of ST and TT. Functional characteristics are divided into: a) correctness of chosen genre of TT, b) functional equivalence of compared texts, c) similarity of their influence on the audience in source and target cultures.

Coincidence of semantic characteristics of ST and TT is defined by the selection of the most suitable variants from semantic field of all units of TT in complex (Ptashkin 2014a; Ptashkin 2014b). For instance, correct variant of the English verb "survive" in the sentence "the tradition survived till the $17^{\text {th }}$ century" is the verb "(fort)bestehen" from semantic field in the German laguage [überleben, erhaltenbleiben, (fort)bestehen] (cf:: "die Tradition bestand bis zum 17. Jahrhundert (fort)"), and in the Russian language - "(про)существовать" which is borrowed from [(про)существовать, (про)жить, (про)быть, сохраниться, остаться] (сf.: "традиция (про)существовала до 17-го века").

\section{Concluding Remarks}

Functional parameters of adequacy have the stylistic and pragmatic orientation. It is suitable to say about the semantic aspect correspondence. The meaning according to G. Frege (Ger. Sinn) is always connected with the function of speech production, its unfluence on the addresee (reader), and the necessity of implementation of communicative intention in a certain situation, etc. (Shul'ga, 1998). Many translators at the beginning of their career mix up with the terms meaning and content. Meaning objectifies extralinguistic reality of the unit or text, content specifies intralinguistic one. Content of the text is more material, it is connected with the form of information presentation, meaning is more abstract, and it correlates with the communicative strategy of the speaker with the aim of creation of speech production, and its functional side. The difference between meaning and content can be seen in German sentence "Das klingt grün?". From the point of view of semantics, this expression is alogical, but pragmatic perspective helps to correlate the unit "grün" with such component as "ökologisch, umwelffreundlich, demokratisch". In this case, the expression does not loose its sense.

No one could demand full realization of equivalence and appropriateness from translators in a definite strategy i.e. 50:50. Relevance of translation as its qualitative expression serves as a criteria, which should be more preferable than equivalence. It does not mean that translator could forget about the correspondence of the contents in ST and TT paying more attention to the quality of translation. Correspondence of the content defines the degree of equivalence of the texts, and it lets use the method of semantic reconstruction of TT, which implies reproduction of content elements of ST by means of TL. For instance, in English "CCTV in operation" - in Russian "ведётся видеонаблюдение".

\section{References}

Prokhorov A. M. (2001). Russian Encyclopaedia. Moscow: Big Russian Encyclopaedia.

Ptashkin, A. S. (2013a). Concept "Genocide" as the Form of the Legal Regulatory Component in the Deviation Category in the English Language. World Applied Sciences Journal, No. 23(5), pp. 621-627.

Ptashkin, A. S. (2013b). The Concept "Ethnocide" Within the Category of Deviation in the English Language. World Applied Sciences Journal, No. 28(6), pp. 826-828.

Ptashkin, A. (2014a). The Concepts of "Beauty" and "Pathology" within the Biological Component of Deviation Category (in the English Language). Xlinguae: European Scientific Language Journal, No. 7 (1), pp. 21-28.

Ptashkin, A. (2014b). Subcategory of Evolution within Deviation Category in the English Language. Mediterranean Journal of Scoial Sciences, № 5 (20), pp. 2327-2331.

Shul'ga E. N. (1998). Hermeneutic analysis of logical texts by G. Frege. In: Modern logic: problems of theory, history, and application in science: issues of All-Russian science conference. St. Petersburg. P. 426-429. 